\title{
Calcium-sensing receptor (version 2019.4) in the IUPHAR/BPS Guide to Pharmacology Database
}

\author{
Daniel Bikle ${ }^{1}$, Hans Bräuner-Osborne ${ }^{2}$, Edward M. Brown ${ }^{3}$, Wenhan Chang ${ }^{1}$, Arthur Conigrave ${ }^{4}$, Fadil Hannan ${ }^{5}$, \\ Katie Leach ${ }^{6}$, Daniela Riccardi ${ }^{7}$, Dolores Shoback ${ }^{1}$, Donald T. Ward ${ }^{8}$ and Polina Yarova ${ }^{7}$ \\ 1. University of California San Francisco, USA \\ 2. University of Copenhagen, Denmark \\ 3. Harvard University, USA \\ 4. University of Sydney, Australia \\ 5. Royal Liverpool University Hospital, UK \\ 6. Monash University, Australia \\ 7. Cardiff University, UK \\ 8. University of Manchester, UK
}

\begin{abstract}
The calcium-sensing receptor (CaS, provisional nomenclature as recommended by NC-IUPHAR [44]) responds to multiple endogenous ligands, including extracellular calcium and other divalent/trivalent cations, polyamines and polycationic peptides, L-amino acids (particularly L-Trp and L-Phe), glutathione and various peptide analogues, ionic strength and extracellular $\mathrm{pH}$ (reviewed in [74]). While divalent/trivalent cations, polyamines and polycations are CaS receptor agonists [14, 106], L-amino acids, glutamyl peptides, ionic strength and $\mathrm{pH}$ are allosteric modulators of agonist function [34, 44, 58, 104, 105]. Indeed, L-amino acids have been identified as "co-agonists", with both concomitant calcium and L-amino acid binding required for full receptor activation $[143,51]$. The sensitivity of the CaS receptor to primary agonists is increased by elevated extracellular $\mathrm{pH}$ [17] or decreased extracellular ionic strength [105]. This receptor bears no sequence or structural relation to the plant calcium receptor, also called $\mathrm{CaS}$.
\end{abstract}

\section{Contents}

This is a citation summary for Calcium-sensing receptor in the Guide to Pharmacology database (GtoPdb). It exists purely as an adjunct to the database to facilitate the recognition of citations to and from the database by citation analyzers. Readers will almost certainly want to visit the relevant sections of the database which are given here under database links.

GtoPdb is an expert-driven guide to pharmacological targets and the substances that act on them. GtoPdb is a reference work which is most usefully represented as an on-line database. As in any publication this work should be appropriately cited, and the papers it cites should also be recognized. This document provides a citation for the relevant parts of the database, and also provides a reference list for the research cited by those parts.

Please note that the database version for the citations given in GtoPdb are to the most recent preceding version in which the family or its subfamilies and targets were substantially changed. The links below are to the current 
version. If you need to consult the cited version, rather than the most recent version, please contact the GtoPdb curators.

\section{Database links}

Calcium-sensing receptor

http://www.guidetopharmacology.org/GRAC/FamilyDisplayForward?familyld=12

Introduction to Calcium-sensing receptor

http://www.guidetopharmacology.org/GRAC/FamilyIntroductionForward?familyld=12

Receptors

CaS receptor

http://www.guidetopharmacology.org/GRAC/ObjectDisplayForward?objectld=54

\section{References}

1. Adams GB, Chabner KT, Alley IR, Olson DP, Szczepiorkowski ZM, Poznansky MC, Kos CH, Pollak MR, Brown EM and Scadden DT. (2006) Stem cell engraftment at the endosteal niche is specified by the calcium-sensing receptor. Nature 439: 599-603 [PMID:16382241]

2. Aslanova UF, Morimoto T, Farajov El, Kumagai N, Nishino M, Sugawara N, Ohsaga A, Maruyama $Y$, Tsuchiya $S$ and Takahashi $S$ et al.. (2006) Chloride-dependent intracellular $\mathrm{pH}$ regulation via extracellular calcium-sensing receptor in the medullary thick ascending limb of the mouse kidney. Tohoku J. Exp. Med. 210: 291-300 [PMID:17146194]

3. Ba J, Brown D and Friedman PA. (2003) Calcium-sensing receptor regulation of PTH-inhibitable proximal tubule phosphate transport. Am. J. Physiol. Renal Physiol. 285: F1233-43 [PMID:12952858]

4. Bai M, Quinn S, Trivedi S, Kifor O, Pearce SH, Pollak MR, Krapcho K, Hebert SC and Brown EM. (1996) Expression and characterization of inactivating and activating mutations in the human $\mathrm{Ca} 2+0-$ sensing receptor. J. Biol. Chem. 271: 19537-45 [PMID:8702647]

5. Balan G, Bauman J, Bhattacharya S, Castrodad M, Healy DR, Herr M, Humphries P, Jennings S, Kalgutkar AS and Kapinos B et al.. (2009) The discovery of novel calcium sensing receptor negative allosteric modulators. Bioorg. Med. Chem. Lett. 19: 3328-32 [PMID:19442519]

6. Bandyopadhyay S, Jeong KH, Hansen JT, Vassilev PM, Brown EM and Chattopadhyay N. (2007) Calcium-sensing receptor stimulates secretion of an interferon-gamma-induced monokine (CXCL10) and monocyte chemoattractant protein-3 in immortalized GnRH neurons. J. Neurosci. Res. 85: 882-95 [PMID:17285630]

7. Blankenship KA, Williams JJ, Lawrence MS, McLeish KR, Dean WL and Arthur JM. (2001) The calciumsensing receptor regulates calcium absorption in MDCK cells by inhibition of PMCA. Am. J. Physiol. Renal Physiol. 280: F815-22 [PMID:11292623]

8. Bradbury RA, Cropley J, Kifor O, Lovicu FJ, de longh RU, Kable E, Brown EM, Seely EW, Peat BB and Conigrave AD. (2002) Localization of the extracellular $\mathrm{Ca}(2+)$-sensing receptor in the human placenta. Placenta. 23: 192-200 [PMID:11945086]

9. Bradbury RA, Sunn KL, Crossley M, Bai M, Brown EM, Delbridge L and Conigrave AD. (1998) Expression of the parathyroid $\mathrm{Ca}(2+)$-sensing receptor in cytotrophoblasts from human term placenta. J. Endocrinol. 156: 425-30 [PMID:9582498]

10. Broadhead GK, Mun HC, Avlani VA, Jourdon O, Church WB, Christopoulos A, Delbridge L and Conigrave AD. (2011) Allosteric modulation of the calcium-sensing receptor by gamma-glutamyl peptides: inhibition of PTH secretion, suppression of intracellular cAMP levels, and a common mechanism of action with Lamino acids. J. Biol. Chem. 286: 8786-97 [PMID:21187282]

11. Brown AJ, Zhong M, Finch J, Ritter C, McCracken R, Morrissey J and Slatopolsky E. (1996) Rat calciumsensing receptor is regulated by vitamin D but not by calcium. Am. J. Physiol. 270: F454-60 [PMID:8780248]

12. Brown EM and Chen CJ. (1989) Calcium, magnesium and the control of PTH secretionBone Miner 5: 
249-57 [PMID:2655774]

13. Brown EM, Fuleihan G el-H, Chen CJ and Kifor O. (1990) A comparison of the effects of divalent and trivalent cations on parathyroid hormone release, 3',5'-cyclic-adenosine monophosphate accumulation, and the levels of inositol phosphates in bovine parathyroid cells. Endocrinology 127: 1064-71 [PMID:2167204]

14. Brown EM, Gamba G, Riccardi D, Lombardi M, Butters R, Kifor O, Sun A, Hediger MA, Lytton J and Hebert SC. (1993) Cloning and characterization of an extracellular $\mathrm{Ca}(2+)$-sensing receptor from bovine parathyroid. Nature 366: 575-80 [PMID:8255296]

15. Brown EM, Katz C, Butters R and Kifor O. (1991) Polyarginine, polylysine, and protamine mimic the effects of high extracellular calcium concentrations on dispersed bovine parathyroid cells. J. Bone Miner. Res. 6 : 1217-25 [PMID:1666808]

16. Bräuner-Osborne H, Jensen AA, Sheppard PO, O'Hara P and Krogsgaard-Larsen P. (1999) The agonistbinding domain of the calcium-sensing receptor is located at the amino-terminal domain. J. Biol. Chem.

274: 18382-6 [PMID:10373443]

17. Campion KL, McCormick WD, Warwicker J, Khayat ME, Atkinson-Dell R, Steward MC, Delbridge LW, Mun HC, Conigrave AD and Ward DT. (2015) Pathophysiologic Changes in Extracellular pH Modulate Parathyroid Calcium-Sensing Receptor Activity and Secretion via a Histidine-Independent Mechanism. J. Am. Soc. Nephrol. 26: 2163-71 [PMID:25556167]

18. Canaff L, Petit JL, Kisiel M, Watson PH, Gascon-Barré M and Hendy GN. (2001) Extracellular calciumsensing receptor is expressed in rat hepatocytes. coupling to intracellular calcium mobilization and stimulation of bile flow. J. Biol. Chem. 276: 4070-9 [PMID:11071898]

19. Chang W, Pratt S, Chen TH, Nemeth E, Huang Z and Shoback D. (1998) Coupling of calcium receptors to inositol phosphate and cyclic AMP generation in mammalian cells and Xenopus laevis oocytes and immunodetection of receptor protein by region-specific antipeptide antisera. J Bone Miner Res. 13: 570580 [PMID:9556057]

20. Chang W, Tu C, Chen TH, Bikle D and Shoback D. (2008) The extracellular calcium-sensing receptor (CaSR) is a critical modulator of skeletal development. Sci Signal1: ra1 [PMID:18765830]

21. Chang W, Tu C, Chen TH, Komuves L, Oda Y, Pratt SA, Miller S and Shoback D. (1999) Expression and signal transduction of calcium-sensing receptors in cartilage and bone. Endocrinology 140: 5883-93 [PMID:10579354]

22. Chang W, Tu C, Cheng Z, Rodriguez L, Chen TH, Gassmann M, Bettler B, Margeta M, Jan LY and Shoback D. (2007) Complex formation with the Type B gamma-aminobutyric acid receptor affects the expression and signal transduction of the extracellular calcium-sensing receptor. Studies with HEK-293 cells and neurons. J. Biol. Chem. 282: 25030-40 [PMID:17591780]

23. Chattopadhyay N, Cheng I, Rogers K, Riccardi D, Hall A, Diaz R, Hebert SC, Soybel DI and Brown EM. (1998) Identification and localization of extracellular $\mathrm{Ca}(2+)$-sensing receptor in rat intestine. Am. J. Physiol. 274: G122-30 [PMID:9458781]

24. Chattopadhyay N, Evliyaoglu C, Heese O, Carroll R, Sanders J, Black P and Brown EM. (2000) Regulation of secretion of PTHrP by $\mathrm{Ca}(2+)$-sensing receptor in human astrocytes, astrocytomas, and meningiomas. Am. J. Physiol., Cell Physiol. 279: C691-9 [PMID:10942719]

25. Chattopadhyay N, Yano S, Tfelt-Hansen J, Rooney P, Kanuparthi D, Bandyopadhyay S, Ren X, Terwilliger E and Brown EM. (2004) Mitogenic action of calcium-sensing receptor on rat calvarial osteoblasts. Endocrinology 145: 3451-62 [PMID:15084499]

26. Chattopadhyay N, Ye C, Singh DP, Kifor O, Vassilev PM, Shinohara T, Chylack Jr LT and Brown EM. (1997) Expression of extracellular calcium-sensing receptor by human lens epithelial cells. Biochem. Biophys. Res. Commun. 233: 801-5 [PMID:9168937]

27. Chattopadhyay N, Ye C, Yamaguchi T, Nakai M, Kifor O, Vassilev PM, Nishimura RN and Brown EM. (1999) The extracellular calcium-sensing receptor is expressed in rat microglia and modulates an outward K+ channel. J. Neurochem. 72: 1915-22 [PMID:10217268]

28. Chattopadhyay N, Ye CP, Yamaguchi T, Kifor O, Vassilev PM, Nishimura R and Brown EM. (1998) Extracellular calcium-sensing receptor in rat oligodendrocytes: expression and potential role in regulation 
of cellular proliferation and an outward K+ channel. Glia 24: 449-58 [PMID:9814825]

29. Chen CJ, Barnett JV, Congo DA and Brown EM. (1989) Divalent cations suppress 3',5'-adenosine monophosphate accumulation by stimulating a pertussis toxin-sensitive guanine nucleotide-binding protein in cultured bovine parathyroid cells. Endocrinology 124: 233-9 [PMID:2462488]

30. Cheng I, Klingensmith ME, Chattopadhyay N, Kifor O, Butters RR, Soybel DI and Brown EM. (1998) Identification and localization of the extracellular calcium-sensing receptor in human breast. J. Clin. Endocrinol. Metab. 83: 703-7 [PMID:9467597]

31. Cheng I, Qureshi I, Chattopadhyay N, Qureshi A, Butters RR, Hall AE, Cima RR, Rogers KV, Hebert SC and Geibel JP et al.. (1999) Expression of an extracellular calcium-sensing receptor in rat stomach. Gastroenterology 116: 118-26 [PMID:9869609]

32. Cheng Z, Tu C, Rodriguez L, Chen TH, Dvorak MM, Margeta M, Gassmann M, Bettler B, Shoback D and Chang W. (2007) Type B gamma-aminobutyric acid receptors modulate the function of the extracellular $\mathrm{Ca} 2+-$ sensing receptor and cell differentiation in murine growth plate chondrocytes. Endocrinology 148: 4984-92 [PMID:17615148]

33. Conigrave AD, Mun HC, Delbridge L, Quinn SJ, Wilkinson M and Brown EM. (2004) L-amino acids regulate parathyroid hormone secretion. J. Biol. Chem. 279: 38151-9 [PMID:15234970]

34. Conigrave AD, Quinn SJ and Brown EM. (2000) L-amino acid sensing by the extracellular Ca2+-sensing receptor. Proc. Natl. Acad. Sci. U.S.A. 97: 4814-9 [PMID:10781086]

35. Cook AE, Mistry SN, Gregory KJ, Furness SG, Sexton PM, Scammells PJ, Conigrave AD, Christopoulos A and Leach K. (2015) Biased allosteric modulation at the CaS receptor engendered by structurally diverse calcimimetics. Br. J. Pharmacol. 172: 185-200 [PMID:25220431]

36. Dauban P, Ferry S, Faure H, Ruat M and Dodd RH. (2000) N1-Arylsulfonyl-N2-(1-aryl)ethyl-3phenylpropane-1,2-diamines as novel calcimimetics acting on the calcium sensing receptor. Bioorg. Med. Chem. Lett. 10: 2001-4 [PMID:10987436]

37. Davey AE, Leach K, Valant C, Conigrave AD, Sexton PM and Christopoulos A. (2012) Positive and negative allosteric modulators promote biased signaling at the calcium-sensing receptor. Endocrinology 153: 1232-41 [PMID:22210744]

38. de Jesus Ferreira MC, Héliès-Toussaint C, Imbert-Teboul M, Bailly C, Verbavatz JM, Bellanger AC and Chabardès D. (1998) Co-expression of a Ca2+-inhibitable adenylyl cyclase and of a Ca2+-sensing receptor in the cortical thick ascending limb cell of the rat kidney. Inhibition of hormone-dependent cAMP accumulation by extracellular Ca2+. J. Biol. Chem. 273: 15192-202 [PMID:9614133]

39. Desfleurs E, Wittner M, Pajaud S, Nitschke R, Rajerison RM and Di Stefano A. (1999) The Ca2+-sensing receptor in the rabbit cortical thick ascending limb (CTAL) is functionally not coupled to phospholipase C. Pflugers Arch. 437: 716-23 [PMID:10087149]

40. Dvorak MM, Siddiqua A, Ward DT, Carter DH, Dallas SL, Nemeth EF and Riccardi D. (2004) Physiological changes in extracellular calcium concentration directly control osteoblast function in the absence of calciotropic hormones. Proc. Natl. Acad. Sci. U.S.A. 101: 5140-5 [PMID:15051872]

41. Emanuel RL, Adler GK, Kifor O, Quinn SJ, Fuller F, Krapcho K and Brown EM. (1996) Calcium-sensing receptor expression and regulation by extracellular calcium in the AtT-20 pituitary cell line. Mol. Endocrinol. 10: 555-65 [PMID:8732686]

42. Fatherazi S, Belton CM, Cai S, Zarif S, Goodwin PC, Lamont RJ and Izutsu KT. (2004) Calcium receptor message, expression and function decrease in differentiating keratinocytes. Pflugers Arch. 448: 93-104 [PMID:14770313]

43. Ferry S, Chatel B, Dodd RH, Lair C, Gully D, Maffrand JP and Ruat M. (1997) Effects of divalent cations and of a calcimimetic on adrenocorticotropic hormone release in pituitary tumor cells. Biochem. Biophys. Res. Commun. 238: 866-73 [PMID:9325183]

44. Foord SM, Bonner TI, Neubig RR, Rosser EM, Pin JP, Davenport AP, Spedding M and Harmar AJ. (2005) International Union of Pharmacology. XLVI. G protein-coupled receptor list. Pharmacol. Rev. 57: 279-88 [PMID:15914470]

45. Freichel M, Zink-Lorenz A, Holloschi A, Hafner M, Flockerzi V and Raue F. (1996) Expression of a 
calcium-sensing receptor in a human medullary thyroid carcinoma cell line and its contribution to calcitonin secretion. Endocrinology 137: 3842-8 [PMID:8756555]

46. Fudge NJ and Kovacs CS. (2004) Physiological studies in heterozygous calcium sensing receptor (CaSR) gene-ablated mice confirm that the CaSR regulates calcitonin release in vivo. BMC Physiol. 4: 5 [PMID:15099400]

47. Gama L, Wilt SG and Breitwieser GE. (2001) Heterodimerization of calcium sensing receptors with metabotropic glutamate receptors in neurons. J. Biol. Chem. 276: 39053-9 [PMID:11489900]

48. Garrett JE, Tamir H, Kifor O, Simin RT, Rogers KV, Mithal A, Gagel RF and Brown EM. (1995) Calcitoninsecreting cells of the thyroid express an extracellular calcium receptor gene. Endocrinology 136: 5202-11 [PMID:7588259]

49. Gavai AV, Vaz RJ, Mikkilineni AB, Roberge JY, Liu Y, Lawrence RM, Corte JR, Yang W, Bednarz M and Dickson Jr JK et al.. (2005) Discovery of novel 1-arylmethyl pyrrolidin-2-yl ethanol amines as calciumsensing receptor antagonists. Bioorg. Med. Chem. Lett. 15: 5478-82 [PMID:16216508]

50. Geibel J, Sritharan K, Geibel R, Geibel P, Persing JS, Seeger A, Roepke TK, Deichstetter M, Prinz C, Cheng SX, Martin D and Hebert SC. (2006) Calcium-sensing receptor abrogates secretagogue- induced increases in intestinal net fluid secretion by enhancing cyclic nucleotide destruction. Proc Natl Acad Sci U $S$ A 103: 9390-9397 [PMID:16760252]

51. Geng Y, Mosyak L, Kurinov I, Zuo H, Sturchler E, Cheng TC, Subramanyam P, Brown AP, Brennan SC and Mun HC et al.. (2016) Structural mechanism of ligand activation in human calcium-sensing receptor. Elife 5: [PMID:27434672]

52. Gerbino A, Ruder WC, Curci S, Pozzan T, Zaccolo M and Hofer AM. (2005) Termination of cAMP signals by $\mathrm{Ca} 2+$ and $\mathrm{G}($ alpha)i via extracellular $\mathrm{Ca} 2+$ sensors: a link to intracellular $\mathrm{Ca} 2+$ oscillations. J. Cell Biol. 171: 303-12 [PMID:16247029]

53. Haden ST, Brown EM, Stoll AL, Scott J and Fuleihan GE. (1999) The effect of lithium on calcium-induced changes in adrenocorticotrophin levels. J. Clin. Endocrinol. Metab. 84: 198-200 [PMID:9920083]

54. Handlogten ME, Huang C, Shiraishi N, Awata H and Miller RT. (2001) The Ca2+-sensing receptor activates cytosolic phospholipase A2 via a Gqalpha -dependent ERK-independent pathway. J. Biol. Chem. 276: 13941-8 [PMID:11278341]

55. Hannan FM, Babinsky VN and Thakker RV. (2016) Disorders of the calcium-sensing receptor and partner proteins: insights into the molecular basis of calcium homeostasis. J. Mol. Endocrinol. 57: R127-42 [PMID:27647839]

56. Hatem S, Hoyaux D, De Decker V, Appelboom T, Pochet R and Steinfeld S. (2002) Expression of calciumsensing receptor in human minor salivary glands. Clin Exp Rheumatol. 20: 576-576 [PMID:12175122]

57. Hauache OM, Hu J, Ray K, Xie R, Jacobson KA and Spiegel AM. (2000) Effects of a calcimimetic compound and naturally activating mutations on the human $\mathrm{Ca} 2+$ receptor and on $\mathrm{Ca} 2+$ receptor/metabotropic glutamate chimeric receptors. Endocrinology 141: 4156-63 [PMID:11089548]

58. Ho C, Conner DA, Pollak MR, Ladd DJ, Kifor O, Warren HB, Brown EM, Seidman JG and Seidman CE. (1995) A mouse model of human familial hypocalciuric hypercalcemia and neonatal severe hyperparathyroidism. Nat. Genet. 11: 389-94 [PMID:7493018]

59. Huang C, Handlogten ME and Miller RT. (2002) Parallel activation of phosphatidylinositol 4-kinase and phospholipase $C$ by the extracellular calcium-sensing receptor. J. Biol. Chem. 277: 20293-300 [PMID:11907035]

60. Huang C, Hujer KM, Wu Z and Miller RT. (2004) The Ca2+-sensing receptor couples to Galpha12/13 to activate phospholipase D in Madin-Darby canine kidney cells. Am. J. Physiol., Cell Physiol. 286: C22-30 [PMID:12954603]

61. Itami A, Kato M, Komoto I, Doi R, Hosotani R, Shimada $Y$ and Imamura M. (2001) Human gastrinoma cells express calcium-sensing receptor. Life Sci. 70: 119-29 [PMID:11787938]

62. Janicic N, Soliman E, Pausova Z, Seldin MF, Rivière M, Szpirer J, Szpirer C and Hendy GN. (1995) Mapping of the calcium-sensing receptor gene (CASR) to human chromosome 3q13.3-21 by fluorescence in situ hybridization, and localization to rat chromosome 11 and mouse chromosome 16. Mamm. Genome 


\section{6: 798-801 [PMID:8597637]}

63. Kessler A, Faure H, Petrel C, Ruat M, Dauban P and Dodd RH. (2004) N2-benzyl-N1-(1-(1-naphthyl)ethyl)3-phenylpropane-1,2-diamines and conformationally restrained indole analogues: development of calindol as a new calcimimetic acting at the calcium sensing receptor. Bioorg. Med. Chem. Lett. 14: 3345-9 [PMID:15149704]

64. Kessler A, Faure H, Roussanne MC, Ferry S, Ruat M, Dauban P and Dodd RH. (2004) N(1)-Arylsulfonyl$\mathrm{N}(2)$-(1-(1-naphthyl)ethyl)-1,2-diaminocyclohexanes: a new class of calcilytic agents acting at the calciumsensing receptor. Chembiochem 5: 1131-6 [PMID:15300839]

65. Kiefer L, Leiris $\mathrm{S}$ and Dodd RH. (2011) Novel calcium sensing receptor ligands: a patent survey.Expert Opin Ther Pat 21: 681-98 [PMID:21406038]

66. Kifor O, Diaz R, Butters R and Brown EM. (1997) The Ca2+-sensing receptor (CaR) activates phospholipases $\mathrm{C}, \mathrm{A} 2$, and $\mathrm{D}$ in bovine parathyroid and CaR-transfected, human embryonic kidney (HEK293) cells. J. Bone Miner. Res. 12: 715-25 [PMID:9144337]

67. Kifor O, MacLeod RJ, Diaz R, Bai M, Yamaguchi T, Yao T, Kifor I and Brown EM. (2001) Regulation of MAP kinase by calcium-sensing receptor in bovine parathyroid and CaR-transfected HEK293 cells. Am J Physiol Renal Physiol. 280: F291-F302 [PMID:11208605]

68. Komoto I, Kato M, Itami A, Shimada Y, Doi R, Hosotani R and Imamura M. (2003) Expression and function of the calcium-sensing receptor in pancreatic islets and insulinoma cells. Pancreas 26: 178-84 [PMID:12604917]

69. Komuves L, Oda Y, Tu CL, Chang WH, Ho-Pao CL, Mauro T and Bikle DD. (2002) Epidermal expression of the full-length extracellular calcium-sensing receptor is required for normal keratinocyte differentiation. $J$. Cell. Physiol. 192: 45-54 [PMID:12115735]

70. Kumar S, Matheny CJ, Hoffman SJ, Marquis RW, Schultz M, Liang X, Vasko JA, Stroup GB, Vaden VR and Haley $\mathrm{H}$ et al.. (2010) An orally active calcium-sensing receptor antagonist that transiently increases plasma concentrations of PTH and stimulates bone formation. Bone 46: 534-42 [PMID:19786130]

71. Kwak JO, Kwak J, Kim HW, On KJ, Kim YT, Jung SM and Cha SH. (2005) The extracellular calcium sensing receptor is expressed in mouse mesangial cells and modulates cell proliferation. Exp. Mol. Med. 37: 457-65 [PMID:16264270]

72. Kállay E, Bonner E, Wrba F, Thakker RV, Peterlik M and Cross HS. (2003) Molecular and functional characterization of the extracellular calcium-sensing receptor in human colon cancer cells. Oncol. Res. 13: 551-9 [PMID:12899245]

73. Leach K, Gregory KJ, Kufareva I, Khajehali E, Cook AE, Abagyan R, Conigrave AD, Sexton PM and Christopoulos A. (2016) Towards a structural understanding of allosteric drugs at the human calciumsensing receptor. Cell Res. 26: 574-92 [PMID:27002221]

74. Leach K, Sexton PM, Christopoulos A and Conigrave AD. (2014) Engendering biased signalling from the calcium-sensing receptor for the pharmacotherapy of diverse disorders. Br. J. Pharmacol. 171: 1142-55 [PMID:24111791]

75. Leach K, Wen A, Cook AE, Sexton PM, Conigrave AD and Christopoulos A. (2013) Impact of clinically relevant mutations on the pharmacoregulation and signaling bias of the calcium-sensing receptor by positive and negative allosteric modulators. Endocrinology 154: 1105-16 [PMID:23372019]

76. Letz S, Haag C, Schulze E, Frank-Raue K, Raue F, Hofner B, Mayr B and Schöfl C. (2014) Amino alcohol(NPS-2143) and quinazolinone-derived calcilytics (ATF936 and AXT914) differentially mitigate excessive signalling of calcium-sensing receptor mutants causing Bartter syndrome Type 5 and autosomal dominant hypocalcemia. PLOS ONE 9: e115178 [PMID:25506941]

77. Ma JN, Owens M, Gustafsson M, Jensen J, Tabatabaei A, Schmelzer K, Olsson R and Burstein ES. (2011) Characterization of highly efficacious allosteric agonists of the human calcium-sensing receptor. $J$. Pharmacol. Exp. Ther. 337: 275-84 [PMID:21239511]

78. MacLeod RJ, Chattopadhyay N and Brown EM. (2003) PTHrP stimulated by the calcium-sensing receptor requires MAP kinase activation. Am. J. Physiol. Endocrinol. Metab. 284: E435-42 [PMID:12388158]

79. MacLeod RJ, Yano S, Chattopadhyay N and Brown EM. (2004) Extracellular calcium-sensing receptor 
transactivates the epidermal growth factor receptor by a triple-membrane-spanning signaling mechanism. Biochem. Biophys. Res. Commun. 320: 455-60 [PMID:15219850]

80. Mamillapalli R and Wysolmerski J. (2010) The calcium-sensing receptor couples to Galpha(s) and regulates PTHrP and ACTH secretion in pituitary cells. J. Endocrinol. 204: 287-97 [PMID:20032198]

81. Mantovani G, Corbetta S, Romoli R, Alberti L, Beck-Peccoz P and Spada A. (2001) Absence of thyroid transcription factor-1 expression in human parathyroid and pituitary glands. Mol. Cell. Endocrinol. 182: 13-7 [PMID:11500234]

82. McNeil L, Hobson S, Nipper V and Rodland KD. (1998) Functional calcium-sensing receptor expression in ovarian surface epithelial cells. Am. J. Obstet. Gynecol. 178: 305-13 [PMID:9500491]

83. McNeil SE, Hobson SA, Nipper V and Rodland KD. (1998) Functional calcium-sensing receptors in rat fibroblasts are required for activation of SRC kinase and mitogen-activated protein kinase in response to extracellular calcium. J Biol Chem. 273: 1114-1120 [PMID:9422777]

84. Mitsuma T, Rhue N, Kayama M, Mori Y, Adachi K, Yokoi Y, Ping J, Nogimori T and Hirooka Y. (1999) Distribution of calcium sensing receptor in rats: an immunohistochemical study. Endocr Regul 33: 55-9 [PMID:10467425]

85. Miyazaki H, Tsubakimoto J, Yasuda K, Takamuro I, Sakurai O, Yanagida T and Hisada Y. (2013) Arylalkylamine compound and process for preparing the same. Patent number: US8362274 B2.

86. Motoyama $\mathrm{HI}$ and Friedman PA. (2002) Calcium-sensing receptor regulation of PTH-dependent calcium absorption by mouse cortical ascending limbs. Am. J. Physiol. Renal Physiol. 283: F399-406 [PMID:12167589]

87. Nagy E and Rigby WF. (1995) Glyceraldehyde-3-phosphate dehydrogenase selectively binds AU-rich RNA in the NAD(+)-binding region (Rossmann fold). J. Biol. Chem. 270: 2755-63 [PMID:7531693]

88. Nemeth EF. (2013) Allosteric modulators of the extracellular calcium receptor.Drug Discov Today Technol 10: e277-84 [PMID:24050279]

89. Nemeth EF. (2004) Calcimimetic and calcilytic drugs: just for parathyroid cells? Cell Calcium 35: 283-9 [PMID:15200152]

90. Nemeth EF, Delmar EG, Heaton WL, Miller MA, Lambert LD, Conklin RL, Gowen M, Gleason JG, Bhatnagar PK and Fox J. (2001) Calcilytic compounds: potent and selective $\mathrm{Ca} 2+$ receptor antagonists that stimulate secretion of parathyroid hormone. J. Pharmacol. Exp. Ther. 299: 323-31 [PMID:11561095]

91. Nemeth EF, Heaton WH, Miller M, Fox J, Balandrin MF, Van Wagenen BC, Colloton M, Karbon W, Scherrer J and Shatzen E et al.. (2004) Pharmacodynamics of the type Il calcimimetic compound cinacalcet HCl. J. Pharmacol. Exp. Ther. 308: 627-35 [PMID:14593085]

92. Nemeth EF and Scarpa A. (1986) Cytosolic Ca2+ and the regulation of secretion in parathyroid cells. FEBS Lett. 203: 15-19 [PMID:3755106]

93. Nemeth EF, Steffey ME, Hammerland LG, Hung BC, Van Wagenen BC, DelMar EG and Balandrin MF. (1998) Calcimimetics with potent and selective activity on the parathyroid calcium receptor. Proc. Natl. Acad. Sci. U.S.A. 95: 4040-5 [PMID:9520489]

94. Oda Y, Tu CL, Chang W, Crumrine D, Kömüves L, Mauro T, Elias PM and Bikle DD. (2000) The calcium sensing receptor and its alternatively spliced form in murine epidermal differentiation. J. Biol. Chem. 275: 1183-90 [PMID:10625662]

95. Oda Y, Tu CL, Pillai S and Bikle DD. (1998) The calcium sensing receptor and its alternatively spliced form in keratinocyte differentiation. J. Biol. Chem. 273: 23344-52 [PMID:9722568]

96. Ogata S, Kubota Y, Satoh S, Ito S, Takeuchi H, Ashizuka M and Shirasuna K. (2006) Ca2+ stimulates COX-2 expression through calcium-sensing receptor in fibroblasts. Biochem. Biophys. Res. Commun. 351: 808-14 [PMID:17097611]

97. Ohsu T, Amino Y, Nagasaki H, Yamanaka T, Takeshita S, Hatanaka T, Maruyama Y, Miyamura N and Eto Y. (2010) Involvement of the calcium-sensing receptor in human taste perception. J. Biol. Chem. 285: 1016-22 [PMID:19892707]

98. Olszak IT, Poznansky MC, Evans RH, Olson D, Kos C, Pollak MR, Brown EM and Scadden DT. (2000) Extracellular calcium elicits a chemokinetic response from monocytes in vitro and in vivo. J. Clin. Invest. 
105: 1299-305 [PMID:10792005]

99. Peiris D, Pacheco I, Spencer C and MacLeod RJ. (2007) The extracellular calcium-sensing receptor reciprocally regulates the secretion of BMP-2 and the BMP antagonist Noggin in colonic myofibroblasts. Am. J. Physiol. Gastrointest. Liver Physiol. 292: G753-66 [PMID:17138967]

100. Petrel C, Kessler A, Dauban P, Dodd RH, Rognan D and Ruat M. (2004) Positive and negative allosteric modulators of the $\mathrm{Ca2+-sensing} \mathrm{receptor} \mathrm{interact} \mathrm{within} \mathrm{overlapping} \mathrm{but} \mathrm{not} \mathrm{identical} \mathrm{binding} \mathrm{sites} \mathrm{in} \mathrm{the}$ transmembrane domain. J. Biol. Chem. 279: 18990-7 [PMID:14976203]

101. Petrel C, Kessler A, Maslah F, Dauban P, Dodd RH, Rognan D and Ruat M. (2003) Modeling and mutagenesis of the binding site of Calhex 231, a novel negative allosteric modulator of the extracellular $\mathrm{Ca}(2+)$-sensing receptor. J. Biol. Chem. 278: 49487-94 [PMID:14506236]

102. Pi M, Faber P, Ekema G, Jackson PD, Ting A, Wang N, Fontilla-Poole M, Mays RW, Brunden KR and Harrington JJ et al.. (2005) Identification of a novel extracellular cation-sensing G-protein-coupled receptor. J. Biol. Chem. 280: 40201-9 [PMID:16199532]

103. Pi M, Spurney RF, Tu Q, Hinson T and Quarles LD. (2002) Calcium-sensing receptor activation of rho involves filamin and rho-guanine nucleotide exchange factor. Endocrinology 143: 3830-8 [PMID:12239094]

104. Quinn SJ, Bai M and Brown EM. (2004) pH Sensing by the calcium-sensing receptor J. Biol. Chem. 279: 37241-9 [PMID:15201280]

105. Quinn SJ, Kifor O, Trivedi S, Diaz R, Vassilev P and Brown E. (1998) Sodium and ionic strength sensing by the calcium receptor. J. Biol. Chem. 273: 19579-86 [PMID:9677383]

106. Quinn SJ, Ye CP, Diaz R, Kifor O, Bai M, Vassilev P and Brown E. (1997) The Ca2+-sensing receptor: a target for polyamines. Am. J. Physiol. 273: C1315-23 [PMID:9357776]

107. Remy C, Kirchhoff P, Hafner P, Busque SM, Müeller MK, Geibel JP and Wagner CA. (2007) Stimulatory pathways of the Calcium-sensing receptor on acid secretion in freshly isolated human gastric glands. Cell. Physiol. Biochem. 19: 33-42 [PMID:17310098]

108. Riccardi D, Hall AE, Chattopadhyay N, Xu JZ, Brown EM and Hebert SC. (1998) Localization of the extracellular $\mathrm{Ca} 2+$ /polyvalent cation-sensing protein in rat kidney. Am. J. Physiol. 274: F611-22 [PMID:9530279]

109. Riccardi D, Park J, Lee WS, Gamba G, Brown EM and Hebert SC. (1995) Cloning and functional expression of a rat kidney extracellular calcium/polyvalent cation-sensing receptor. Proc. Natl. Acad. Sci. U.S.A. 92: 131-5 [PMID:7816802]

110. Riccardi D, Traebert M, Ward DT, Kaissling B, Biber J, Hebert SC and Murer H. (2000) Dietary phosphate and parathyroid hormone alter the expression of the calcium-sensing receptor $(\mathrm{CaR})$ and the $\mathrm{Na+-}$ dependent Pi transporter (NaPi-2) in the rat proximal tubule. Pflugers Arch. 441: 379-387 [PMID:11211126]

111. Rodriguez L, Tu C, Cheng Z, Chen TH, Bikle D, Shoback D and Chang W. (2005) Expression and functional assessment of an alternatively spliced extracellular $\mathrm{Ca2+-sensing} \mathrm{receptor} \mathrm{in} \mathrm{growth} \mathrm{plate}$ chondrocytes. Endocrinology 146: 5294-303 [PMID:16166224]

112. Rogers KV, Dunn CK, Hebert SC and Brown EM. (1997) Localization of calcium receptor mRNA in the adult rat central nervous system by in situ hybridization. Brain Res. 744: 47-56 [PMID:9030412]

113. Rutten MJ, Bacon KD, Marlink KL, Stoney M, Meichsner CL, Lee FP, Hobson SA, Rodland KD, Sheppard $\mathrm{BC}$ and Trunkey DD et al.. (1999) Identification of a functional Ca2+-sensing receptor in normal human gastric mucous epithelial cells. Am. J. Physiol. 277: G662-70 [PMID:10484392]

114. Rácz GZ, Kittel A, Riccardi D, Case RM, Elliott AC and Varga G. (2002) Extracellular calcium sensing receptor in human pancreatic cells. Gut 51: 705-11 [PMID:12377811]

115. Sanders JL, Chattopadhyay N, Kifor O, Yamaguchi T and Brown EM. (2001) Ca(2+)-sensing receptor expression and PTHrP secretion in PC-3 human prostate cancer cells. Am. J. Physiol. Endocrinol. Metab. 281: E1267-74 [PMID:11701443]

116. Sanders JL, Chattopadhyay N, Kifor O, Yamaguchi T and Brown EM. (2000) Extracellular calcium-sensing receptor $(\mathrm{CaR})$ expression and its potential role in parathyroid hormone-related peptide (PTHrP) secretion in the $\mathrm{H}-500$ rat Leydig cell model of humoral hypercalcemia of malignancy. Biochem. Biophys. Res. 
Commun. 269: 427-32 [PMID:10708570]

117. Sanders JL, Chattopadhyay N, Kifor O, Yamaguchi T, Butters RR and Brown EM. (2000) Extracellular calcium-sensing receptor expression and its potential role in regulating parathyroid hormone-related peptide secretion in human breast cancer cell lines. Endocrinology 141: 4357-4364 [PMID:11108243]

118. Sands JM, Naruse M, Baum M, Jo I, Hebert SC, Brown EM and Harris HW. (1997) Apical extracellular calcium/polyvalent cation-sensing receptor regulates vasopressin-elicited water permeability in rat kidney inner medullary collecting duct. J Clin Invest. 99: 1399-1405 [PMID:9077550]

119. Shalhoub V, Grisanti M, Padagas J, Scully S, Rattan A, Qi M, Varnum B, Vezina C, Lacey D and Martin D. (2003) In vitro studies with the calcimimetic, cinacalcet $\mathrm{HCl}$, on normal human adult osteoblastic and osteoclastic cells. Crit. Rev. Eukaryot. Gene Expr. 13: 89-106 [PMID:14696958]

120. Shcherbakova I, Huang G, Geoffroy OJ, Nair SK, Swierczek K, Balandrin MF, Fox J, Heaton WL and Conklin RL. (2005) Design, new synthesis, and calcilytic activity of substituted 3H-pyrimidin-4-ones. Bioorg. Med. Chem. Lett. 15: 2537-40 [PMID:15863312]

121. Sheinin Y, Kállay E, Wrba F, Kriwanek S, Peterlik M and Cross HS. (2000) Immunocytochemical localization of the extracellular calcium-sensing receptor in normal and malignant human large intestinal mucosa. J. Histochem. Cytochem. 48: 595-602 [PMID:10769043]

122. Shinagawa Y, Inoue T, Katsushima T, Kiguchi T, Ikenogami T, Ogawa N, Fukuda K, Hirata K, Harada K and Takagi $\mathrm{M}$ et al.. (2011) Discovery of a potent and short-acting oral calcilytic with a pulsatile secretion of parathyroid hormone. ACS Med Chem Lett 2: 238-42 [PMID:24900301]

123. Tfelt-Hansen J, Chattopadhyay N, Yano S, Kanuparthi D, Rooney P, Schwarz P and Brown EM. (2004) Calcium-sensing receptor induces proliferation through p38 mitogen-activated protein kinase and phosphatidylinositol 3-kinase but not extracellularly regulated kinase in a model of humoral hypercalcemia of malignancy. Endocrinology 145: 1211-7 [PMID:14645111]

124. Thomsen AR, Hvidtfeldt $M$ and Bräuner-Osborne H. (2012) Biased agonism of the calcium-sensing receptor. Cell Calcium 51: 107-16 [PMID:22192592]

125. Turksen K and Troy TC. (2003) Overexpression of the calcium sensing receptor accelerates epidermal differentiation and permeability barrier formation in vivo. Mech. Dev. 120: 733-44 [PMID:12834872]

126. VanHouten J, Dann P, McGeoch G, Brown EM, Krapcho K, Neville M and Wysolmerski JJ. (2004) The calcium-sensing receptor regulates mammary gland parathyroid hormone-related protein production and calcium transport. J Clin Invest. 113: 598-608 [PMID:14966569]

127. Wada M, Nagano N, Furuya Y, Chin J, Nemeth EF and Fox J. (2000) Calcimimetic NPS R-568 prevents parathyroid hyperplasia in rats with severe secondary hyperparathyroidism. Kidney Int. 57: 50-8 [PMID:10620187]

128. Walter S, Baruch A, Dong J, Tomlinson JE, Alexander ST, Janes J, Hunter T, Yin Q, Maclean D and Bell G et al.. (2013) Pharmacology of AMG 416 (Velcalcetide), a novel peptide agonist of the calcium-sensing receptor, for the treatment of secondary hyperparathyroidism in hemodialysis patients. J. Pharmacol. Exp. Ther. 346: 229-40 [PMID:23674604]

129. Wang M, Yao Y, Kuang D and Hampson DR. (2006) Activation of family C G-protein-coupled receptors by the tripeptide glutathione. J. Biol. Chem. 281: 8864-70 [PMID:16455645]

130. Wang R, Xu C, Zhao W, Zhang J, Cao K, Yang B and Wu L. (2003) Calcium and polyamine regulated calcium-sensing receptors in cardiac tissues. Eur. J. Biochem. 270: 2680-8 [PMID:12787035]

131. Wang Y, Awumey EK, Chatterjee PK, Somasundaram C, Bian K, Rogers KV, Dunn C and Bukoski RD. (2003) Molecular cloning and characterization of a rat sensory nerve Ca2+-sensing receptor. Am J Physiol Cell Physiol. 285: C64-C75 [PMID:12637267]

132. Ward DT and Riccardi D. (2012) New concepts in calcium-sensing receptor pharmacology and signalling. Br. J. Pharmacol. 165: 35-48 [PMID:21627634]

133. Widler L, Altmann E, Beerli R, Breitenstein W, Bouhelal R, Buhl T, Gamse R, Gerspacher M, Halleux C and John MR et al.. (2010) 1-Alkyl-4-phenyl-6-alkoxy-1H-quinazolin-2-ones: a novel series of potent calcium-sensing receptor antagonists. J. Med. Chem. 53: 2250-63 [PMID:20158186]

134. Yamaguchi T, Chattopadhyay N, Kifor O and Brown EM. (1998) Extracellular calcium (Ca2+(0))-sensing 
receptor in a murine bone marrow-derived stromal cell line (ST2): potential mediator of the actions of Ca2+ (o) on the function of ST2 cells. Endocrinology 139: 3561-8 [PMID:9681508]

135. Yamaguchi T, Chattopadhyay N, Kifor O, Butters Jr RR, Sugimoto T and Brown EM. (1998) Mouse osteoblastic cell line (MC3T3-E1) expresses extracellular calcium (Ca2+o)-sensing receptor and its agonists stimulate chemotaxis and proliferation of MC3T3-E1 cells. J. Bone Miner. Res. 13: 1530-8 [PMID:9783541]

136. Yamaguchi T, Chattopadhyay N, Kifor O, Ye C, Vassilev PM, Sanders JL and Brown EM. (2001) Expression of extracellular calcium-sensing receptor in human osteoblastic MG-63 cell line. Am. J. Physiol., Cell Physiol. 280: C382-93 [PMID:11208534]

137. Yamaguchi T, Yamauchi M, Sugimoto T, Chauhan D, Anderson KC, Brown EM and Chihara K. (2002) The extracellular calcium $\mathrm{Ca2}+0$-sensing receptor is expressed in myeloma cells and modulates cell proliferation. Biochem. Biophys. Res. Commun. 299: 532-8 [PMID:12459170]

138. Yamaguchi T, Ye C, Chattopadhyay N, Sanders JL, Vassilev PM and Brown EM. (2000) Enhanced expression of extracellular calcium sensing receptor in monocyte-differentiated versus undifferentiated HL60 cells: potential role in regulation of a nonselective cation channel. Calcif. Tissue Int. 66: 375-82 [PMID:10773108]

139. Yang W, Wang Y, Roberge JY, Ma Z, Liu Y, Michael Lawrence R, Rotella DP, Seethala R, Feyen JH and Dickson JK. (2005) Discovery and structure-activity relationships of 2-benzylpyrrolidine-substituted aryloxypropanols as calcium-sensing receptor antagonists. Bioorg Med Chem Lett 15: 1225-1228 [PMID:15686947]

140. Yano S, Macleod RJ, Chattopadhyay N, Tfelt-Hansen J, Kifor O, Butters RR and Brown EM. (2004) Calcium-sensing receptor activation stimulates parathyroid hormone-related protein secretion in prostate cancer cells: role of epidermal growth factor receptor transactivation. Bone 35: 664-72 [PMID:15336602]

141. Ye C, Chattopadhyay N, Brown EM and Vassilev PM. (2000) Defective extracellular calcium (Ca(0))sensing receptor $(\mathrm{CaR})$-mediated stimulation of a $\mathrm{Ca}(2+)$-activated potassium channel in glioblastoma cells transfected with a dominant negative CaR. Brain Res Mol Brain Res. 80: 177-187 [PMID:11038250]

142. Ye C, Rogers K, Bai M, Quinn SJ, Brown EM and Vassilev PM. (1996) Agonists of the Ca(2+)-sensing receptor ( $\mathrm{CaR}$ ) activate nonselective cation channels in HEK293 cells stably transfected with the human CaR. Biochem. Biophys. Res. Commun. 226: 572-9 [PMID:8806675]

143. Zhang C, Miller CL, Gorkhali R, Zou J, Huang K, Brown EM and Yang JJ. (2016) Molecular Basis of the Extracellular Ligands Mediated Signaling by the Calcium Sensing Receptor. Front Physiol 7: 441 [PMID:27746744] 